\title{
PENGARUH OPERATING EXPENSES TO OPERATING REVENUES (BOPO), FINANCING TO DEPOSIT RATIO (FDR) DAN NON PERFORMING FINANCING (NPF) TERHADAP PROFITABILITAS BANK UMUM SYARIAH DI INDONESIA
}

\author{
Mella Kusuma Wardannah \\ Fakultas Ekonomi, Universitas Singaperbangsa Karawang \\ email: student@unsika.ac.id \\ Wirman \\ Fakultas Ekonomi, Universitas Singaperbangsa Karawang \\ email: wirman@feb.unsika.ac.id
}

\begin{abstract}
The development of Islamic banking is currently growing rapidly and has gained a lot of trust in the community which greatly affects the nation's economy. This study aims to examine the influence of Operating Expenses to Operating Revenues (BOPO), Financing To Deposit Ratio (FDR) and NonPerforming Financing (NPF) on the Profitability of Islamic Commercial Banks in Indonesia in the 20152019 period. The data is taken from the annual financial reports of Sharia Commercial Banks registered with the Financial Services Authority in 2015-2019 which are published on the official website (www.ojk.co.id) The object of this research was conducted at 6 banks registered with the Financial Services Authority (OJK) with a period of 5 years for the 2015-2016 period. In total there are 6 Sharia commercial banks, namely Bank Muamalat, Bank Mega Syariah, Bank BRI Syariah, Bank BNI Syariah, Bank BCA Syariah, and Bank Mandiri Syariah. The data analysis technique used in the study used the classical assumption test which included normality test, multicollinearity test, heteroscedasticity test, autocorrelation test. To find out the overall picture of each of the variables, this study uses multiple linear regression and hypothesis testing which includes the t test (partial) and the f test simultaneously. The results showed that the BOPO variable had a significant negative effect on ROA, the FDR variable had a significant positive effect on ROA and the NPF variable had no effect on ROA. The results of this study are expected to be a guideline for further research and be useful for the management of Islamic Commercial Banks in managing the company.
\end{abstract}

Keywords : Operating Expenses To Operating Revenues (BOPO), Financing To Deposit Ratio (FDR), Non Performing Financing (NPF), Profitabilitas (ROA)

Abstrak

Perkembangan perbankan syariah saat ini sudah semakin pesat dan sudah mendapatkan kepercayaan yang banyak kepada masyarakat dimana sangat berpengaruh terhadap perekonomian bangsa. Penelitian ini bertujuan untuk menguji adanya pengaruh Operating Expenses to Operating Revenues (BOPO), Financing To Deposit Ratio (FDR) dan Non Perfoming Financing (NPF) Terhadap Profitabilitas Bank Umum Syariah di Indonesia pada periode 2015-2019. Data diambil dari laporan keuangan tahunan Bank Umum Syariah yang terdaftar di Otoritas Jasa Keuangan pada tahun 20152019 yang dipublikasikan pada situs resmi (www.ojk.co.id). Objek penelitian ini dilakukan pada 6 bank yang terdaftar di Otoritas Jasa Keuangan (OJK) dengan periode selama 5 tahun periode 20152016. Totalnya berjumlah 6 bank umum Syariah yaitu Bank Muamalat, Bank Mega Syariah, Bank BRI Syariah, Bank BNI Syariah, Bank BCA Syariah, dan Bank Mandiri Syariah. Teknik analisis data yang digunakan dalam penelitian menggunakan uji asumsi klasik yang meliputi uji normalitas, uji multikolinierias, uji heteroskedastisitas, uji autokorelasi. Untuk mengetahui gambaran menyeluruh dari tiap variabelnya penelitian ini menggunakan uji regresi linier berganda dan uji hipotesis yang meliputi uji t (parsial) dan uji f secara simultan. Hasil penelitian menunjukkan bahwa variabel BOPO berpengaruh negatif signifikan terhadap ROA, variabel FDR berpengaruh positif signifikan terhadap ROA dan variabel NPF tidak berpengaruh terhadap ROA. Hasil penelitian ini diharapkan agar dapat menjadi pedoman bagi penilitian lanjutan selanjutnya dan bermanfaat bagi manajemen Bank Umum Syariah dalam mengelola perusahaan.

Kata Kunci: Beban Usaha Terhadap Pendapatan Usaha (BOPO), Rasio Pembiayaan Terhadap DPK (FDR), Nilai Pembiayaan Bermasalah Bersih (NPF) Profitabilitas (ROA) 


\section{PENDAHULUAN}

Dalam perkembangan peran perbankan syariah di Indonesia tidak terlepas dari sistem perbankan di Indonesia secara umum. Sistem perbankan syariah juga diatur dalam Undang-Undang No. 10 tahun 1998 yang menjelaskan dimana Bank Umum adalah bank yang tugasnya melaksanakan kegiatan usaha secara konvensional atau berdasarkan prinsip prinsip syariah yang kegiatannya memberikan jasa dalam aktivitas pembayaran. Sesuai dengan tugas dan perannya bank Syariah di indonesia dalam memacu pertumbuhan perekonomian daerah semakin strategis dalam rangka mewujudkan struktur perekonomian yang semakin berimbang dan semakin maju.

Bank Syariah bisa dapat dikatakan menguntungkan padahal tujuan utama bank syriah tidak mencari laba yang tinggi, disebabkan karena produk pembiayaan yang menguntungkan sehingga membuat bank Syariah mendapatkan keuntungan yang lebih rendah dibanding dengan bank konvesional. Keuntungan ini terlihat dari profitabilitas (laba) yang dimana rasio ini digunakan untuk melihat besarnya keuntungan yang didapat pada tiap bank teresebut. Kinerja bank sangat berpengaruh pada profitabilitas (laba) yang didapatkan. Karena jika kinerja bank baik maka akan berpengaruh langsung terhadap laba yang diperoleh yaitu dengan naiknya laba, namun apabila kinerja bank buruk maka laba yang didapatkan akan turun.

Menurut penelitian terdahulu (Djuwita \& Muhammad, 2016), dalammengukur kinerja bank ada dua faktor yang dapat mempengaruhi profitabilitas, yaitu faktor internal dan faktor eksternal. Faktor internal meliputi produk pembiayaan bank, dana pihak ketiga, performance financing, kualitas aset, dan modal. Sedangkan faktor eksternal meliputi regulasi perbankan, struktur pasar, tingkat suku bunga, inflasi dan tingkat pertumbuhan pasar yang dimana faktor ini dapat disebabkan karena pengaruh dari luar. faktor yang dapat mempengaruhi profitabilitas pada penelitian ini yaitu faktor internal meliputi faktor Operating Expenses to Operating Revenues (BOPO) oleh bank umum syariah dan faktor (NPF) non performance financing.

Variable dependen pada penilitan ini yaitu menggunakan nilai profitabilitas bank Syariah yang diukur menggunakan Retrun On Asset (ROA), sedangkan variabel independen diambil dari factor internal yaitu faktor Operating Expenses to Operating Revenues (BOPO) dan faktor performance financing meliputi FDR (financing to deposit ratio) dan NPF (non performing financing). Tujuan penelitian ini yaitu adalah untuk melihat bagaimana pengaruh dana pihak ketiga, FDR, NPF baik sevara simultan maupun parsial terhadap profitabilitas (ROA) bank umum Syariah di Indonesia.

Perbankan Syariah sudah berkomitmen bahwa tidak menggunakan sistem bunga mendapatkan respon yang sangat baik dikalangan masyarakat Indonesia. Pada tahun 2016 pertumbuhan profitabilitas (ROA) perbankan Syariah merupakan angka yang tertinggi yaitu mencapai $2.63 \%$ hal ini menarik antusiasme masyarakat yang tinggi terhadap Bank Syariah. Serta konsep pelanggaran riba atau bunga dalam ekonomi islam berimplikasi pada mendorong pemaksimalan kegiatan ekonomi riil dalam setiap aktivitas perbankan syariah di Indonesia. Sistem pengaplikasian dari perbankan Syariah yaitu kejelasan, transparansi dan konsistensi dari setiap pelaksanaan akad 
yang disepakati oleh nasabah dan bank Syariah tersebut.

Profitabilitas merupakan kemampuan perusahaan, dalam hal ini ialah perusahaan perbankan Untuk menghasilkan laba. Profitabilitas biasanya diukur menggunakan rasio perbandingan rasio yang biasa digunakan untuk mengukur dan membandingkan kinerja profitabilitas pada bank ialah ROE (Retrun On Equity) dan ROA (Retrun On Asset). Namun dalam penilitian ini mengambil ukuran dengan Retrun On Asset. Berikut nilai rata rata perkembangan Retrun On Asset (ROA) pada bank umum Syariah yang terdaftar di OJK tahun 2017-2019.

Grafik I : Perkembangan Retrun On Asset bank umum Syariah yang terdaftar di OJK periode 2015-2019

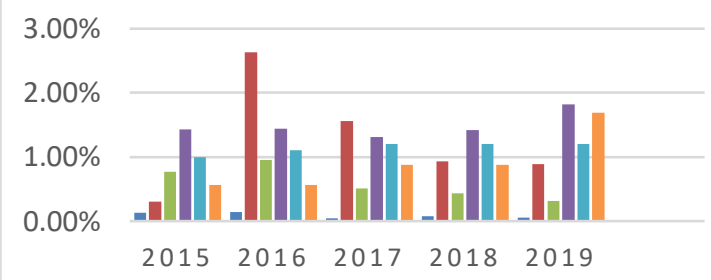

Sumber : Data diolah dari www.ojk.co.id Berdasarkan grafik diatas maka dapat dilihat bahwa fluktuasi dari nilai Retrun On Asset (ROA) pada bank umum Syariah yang terdaftar di OJK menunjukkan hasil dimana nilai rata-rata ROA selama periode tahun 2015-2019 sebesar 1.5\%. Kenaikan ROA tertinggi pada tahun 2016 yaitu sebesar $2.63 \%$ dan angka ROA terkecil ditunjukkan pada tahun 2019 sebesar $0.05 \%$. Angka ini menunjukkan bahwa ROA pada bank umum Syariah mengalami perkembangan yang tidak stabil.

Profitabilitas dapat dikatakan sebagai salah satu indikator yang paling tepat untuk mengukur kinerja suatu perusahaan karena semakin tinggi profotabilitasnya maka semakin baik pula kinerja keuangan suatu perusahaan tersebut. Seperti yang sudah diatur dalam Surat Edaran Bank Indonesia No.06 /23/DPNP tanggal 31 Mei 2004 mengemukakan bahwa adanya tiga rasio yang dapat digunakan sebagai parameter dari profitabilitas bank yaitu net interest margin (NIM), retrun on asset (ROA) dan retrun on equity (ROE), Profitabilitas bank juga dapat ditentukan oleh faktor-faktor yang dapat dikendalikan oleh menejemen yang dimana faktor-faktor manajemen merupakan faktor-faktor yang menggambarkan kebijakan dan keputusan menejemen itu sendiri yaitu seperti penghimpunan dana, manajemen modal, manajemen likuidasi, dan manajemen biaya.

Tujuan dalam penelitian ini adalah untuk mengetahui Pengaruh Operating Expenses to Operating Revenues (BOPO), Financing To Deposit Ratio (FDR) dan Non Perfoming Financing (NPF) Terhadap Profitabilitas Bank Umum Syariah Di Indonesia.

\section{TINJAUAN PUSTAKA}

\subsection{Profitabilitas}

Profitabilitas dapat disebut sebagai kemampuan perusahaan, dalam hal ini yaitu perusahaan perbankan, untuk menghasilkan laba. Rasio profitabilitas yang semakin tinggi maka dapat menarik nasabah untuk menghimpun dana di bank tersebut karena profitabilitas dapat menjadi indikator yang paling tepat untuk mengukur kinerja suatu bank (Npf et al., 2014). Pengertian profitabilitas secara luas adalah kemampuan perusahaan untuk menghasilkan laba dengan menggunakan aktiva atau modal yang dimilikinya.

Retrun On Asset (ROA) adalan rasio keuangan yang digunakan untuk mengukur hubungan laba terhadap total asset. Semakin tinggi nilai ROA maka 
menunjukkan kinerja yang baik bagi suatu perusahaan.

\subsection{Operating Expenses to Operating Revenues (BOPO)}

Biaya Operasional terhadap

Pendapatan Operasional (BOPO) ini merupakan rasio yang sering disebut dengan rasio efisiensi yang digunakan untuk mengukur kemampuan manajemen bank dalam mengendalikan biaya operasioanal terhadap pendapat operasional perusahaan. Maka dapat dikatakan jika semakin tinggi rasio ini menujukkan kondisi perusahaan yang kurang baik karena semakin tinggi biaya maka bank menjadi semakin tidak efisien sehingga perubahan laba operasional makin kecil.

Menurut penelitian terdahulu oleh Mawardi (2005) BOPO berpengaruh negative terhadap ROA. Yuliani (2007) menyatakan bahwa BOPO berpengaruh positif terhadap ROA. Hendrayati (2013) menyatakan bahwa BOPO tidak berpengaruh terhadap ROA.

\subsection{Financing To Deposit Ratio (FDR)}

Financing To Deposit Ratio (FDR) ialah perbandingan antara pembiayaan yang diberikan oleh bank dengan dana pihak ketiga yang berhasil disalurkan oleh bank (Syah, 2018) Secara umum FDR adalah rasio yang menunjukkan kemampuan perbankan dalam menyediakan dana kepada nasabahnya dengan modal yang dimiliki oleh bank maupun dana yang dapat dikumpulkan dari masyarakat atau nasabah dari bank tersebut.

Menurut penelitian terdahulu oleh Suryani (2018) FDR tidak berpengaruh terhadap ROA. Bahri (2013) menyatakan bahwa FDR berpengaruh positif terhadap ROA. Slamet (2014) menyatakan bahwa FDR berpengaruh positif terhadap ROA.

\subsection{Non Perfoming Financing (NPF)}

Non Perfoming Financing (NPF) merupakan rasio yang dipergunakan untuk mengukr rasio terhadap kredit yang disalurkan dengan membandingkan kredit macet dengan jumlah kredit yang disalurkan, dengan demikian maka semakin tinggi rasio ini akan semakin buruk kualitas kredit bank yang menyebabkan jumlah kredit bermasalah semakin besar maka kemungkinan suatu bank dalam kondisi bermasalah dan dapat mempengaruhi nilai profitabilitas pada bank.

Menurut penelitian terdahulu oleh Bahri (2013) NPF berpengaruh positif terhadap ROA. Rahman (2012) menyatakn bahwa NPF berpengaruh negative terhadap ROA. Wibowo (2013) menyatakan bahwa NPF tidak berpengaruh terhadap ROA.

Penelitian ini telah diteliti oleh para peneliti sebelumnya dan mendapatkan hasil yang berbeda, dari perbedaan tersebut maka membuat penelitian lanjutan mengenai Pengaruh Operating Expenses to Operating Revenues (BOPO), Financing To Deposit Ratio (FDR) dan Non Perfoming Financing (NPF) Terhadap Profitabilitas maka perlu dilakukan kembali agar dapat mengimplementasikan fenomena yang baru mengenai perbankan Syariah di Indonesia.

Gambar 1 : Skema Penelitian Variabel Independen (X)

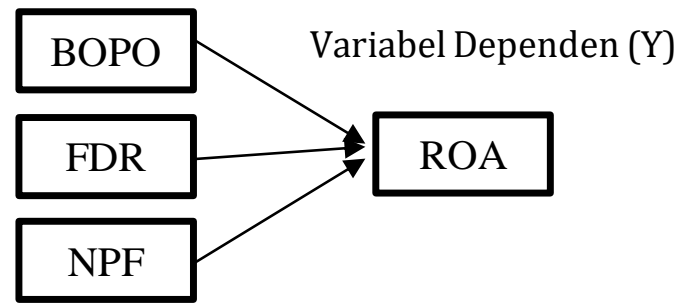




\section{METODE PENELITIAN}

\subsection{Definisi Variabel Penelitian}

\section{a. Profitabilitas}

Pengukuran profitabilitas bank menggunakan Retrun On Asset (ROA). ROA adalah rasio keuangan yang digunakan untuk mengukur hubungan laba terhadap total asset. Semakit tinggi nilai ROA perusahaan maka semakin baik pula kondisi suatu bank tersebut. Perihitungan ROA dalam perbankan dapat dihitung dengan menggunakan rumus :

$$
R O A=\frac{\text { Laba Sebelum Pajak }}{\text { total asset }} \times 100 \%
$$

\section{b. Operating Expenses to Operating Revenues (BOPO)}

Biaya Operasi dan Pendapatan Operasi (BOPO) ini merupakan sumber pendapatan utama yang berasal dari pendapatan bunga yang diperoleh dari penempatan dana dalam bentuk kredit dan pendapatan operasional lainnya. Perhitungan BOPO dalam perbankan dapat dihitung dengan menggunakan rumus :

$$
\mathrm{BOPO}=\frac{\text { Biaya Operasional }}{\text { Pendapatan Operasional }} \times 100 \%
$$

\section{c. Financing To Deposit Ratio (FDR)}

financing To Deposit Ratio (FDR) ini merupakan rasio yang dipergunakan untuk mengukur sudah sejauh mana dana pinjaman yang bersumber dari dana pihak ketiga, tinggi rendahnya rasio ini menunjukkan nilai tingkat likuiditas bank tersebut. Sehingga dapat dikatakan bila semakin tinggi angka FDR suatu bank, berarti digambarkan sebagai bank yang kurang likuid dibanding dengan bank yang mempunyai angka rasio lebih kecil. Perhitungan FDR dalam perbankan dapat dihitung dengan menggunakan rumus :

$$
F D R=\frac{\text { Total Pembiayaan }}{\text { Total DPK }} \times 100 \%
$$

\section{d. Non Perfoming Financing (NPF)}

Non Perfoming Financing (NPF) rasio ini merupakan pembiayaan macet yang sangat berpengaruh terhadap laba Syariah. Non Perfoming Financing (NPF) sangat berhubungan dengan pembiayaan yang disalurkan oleh bank Syariah kepada nasabah, apabila NPF menunjukkan nilai yang rendah diharapkan pendapatan akan meningkat sehingga dapat berpengaruh kepada peningkatannya laba pada bank tersebut, namun sebaliknya apabila nilai NPF tinggi maka pendapatan akan menurun sehingga laba yang didapat akan turun. Perhitungan NPF dalam perbankan dapat dihitung dengan menggunakan rumus :

$$
N P F=\frac{\text { Total Pembiayaan Bermasalah }}{\text { Total Pembiayaan }} \times 100 \%
$$

\subsection{Populasi Dan Sampel}

Objek penelitian ini dilakukan pada 6 bank yang terdaftar di Otoritas Jasa Keuangan (OJK) dengan periode selama 5 tahun periode 2015-2016. Totalnya berjumlah 6 bank umum Syariah yaitu Bank Muamalat, Bank Mega Syariah, Bank BRI Syariah, Bank BNI Syariah, Bank BCA Syariah, dan Bank Mandiri Syariah.

\subsection{Jenis dan Sumber Data}

Data yang diambil untuk penelitian adalah data sekunder yang merupakan bagian jumlah dan karakteristik yang dimiliki oleh populasi. Data diambil dari laporan keuangan tahunan Bank Umum Syariah yang terdaftar di Otoritas Jasa Keuangan pada tahun 2015-2019 yang dipublikasikan pada situs resmi (www.ojk.co.id).

\subsection{Variabel Penelitian}

Penelitian ini menggunakan 4 variabel yang terdiri dari 1 variabel terikat (dependen) dan 3 variabel bebas (independen). Variabel dependen dalam penelitian ini adalah return on asset (ROA) sedangkan variabel independen yang digunakan dalam penelitian ini 
adalah Operating Expenses to Operating Revenues (BOPO), Financing To Deposit Ratio (FDR) dan Non Perfoming Financing (NPF).

\subsection{Teknik Analisis Data}

\section{a. Uji Asumsi Klasik}

1) Uji Normalitas

Uji normalitas bertujuan untuk menguji apakah variabel independent dan variabel dependen dalam model regresi tersebut terdistribusi secara normal. Dalam uji normalitas ini dengan Kolmogorov-Smirnov. Sujarweni (2016 : 72) Pengambilan keputusan dalam uji normalitas kolmogorov -smirnov adalah sebagai berikut : Jika Sig > 0,05 maka data berdistribusi normal Jika Sig $<$ 0,05 maka data tidak berdistribusi normal.

2) Uji Multikolonieritas

Uji multikolonieritas ini bertujuan untuk menguji adakah terdapat korelasi antara variabel independent dan variabel dependen. , uji multikolonieritas diukur dengan nilai tolerance dan VIF. Suatu model regresi yang bebas dari multikolonieritas apabila mempunyai nilai tolerance lebih dari 0,1 dan nilai VIF kurang dari 10.

3) Uji Heteroskedasitisitas

Uji Heteroskedasitisitas ini menguji terjadinya perbedaan variance residual suatu periode pengamatan ke periode pengamatan yang lain. Penyebaran titik titik yang tidak berpola.

4) Uji Autokorelasi

Dalam pengujian autokorelasi menggunakan nilai Durbin Watson yang dimana menguji apakah dalam suatu model mengetahui ada tidaknya korelasi atara variabel pengganggu pada periode tertentu dengan variabel sebelumnya.

\section{b. Uji Regresi Linier Berganda}

Dalam penelitian ini menggunakan regresi linier berganda karena memiliki satu variabel dependen dan dua variabel independent yang dimana bertujuan untuk mengetahui apakah ada pengaruh antara variabel satu dengan variabek yang lainnya.

\section{c. Uji Hipotesis}

1) Uji T (Parsial)

Uji statistik $\mathrm{t}$ digunakan untuk mengetahui seberapa jauh pengaruh satu variabel independen secara individual dalam menjelaskan variabel-variabel dependen. Sujarweni (2016: 359)

\section{2) Uji F (Simultan)}

Uji statistik $\mathrm{F}$ digunakan untuk mengetahui apakah semua variabel independen yang dimasukkan dalam model regresi mempunyai pengaruh secara bersama-sama atau simultan terhadap variabel dependen. Sujarweni (2016:360).

\section{HASIL DAN PEMBAHASAN 4.1 Uji Asumsi Klasik}

Table 2 : Hasil Uji Asumsi Klasik

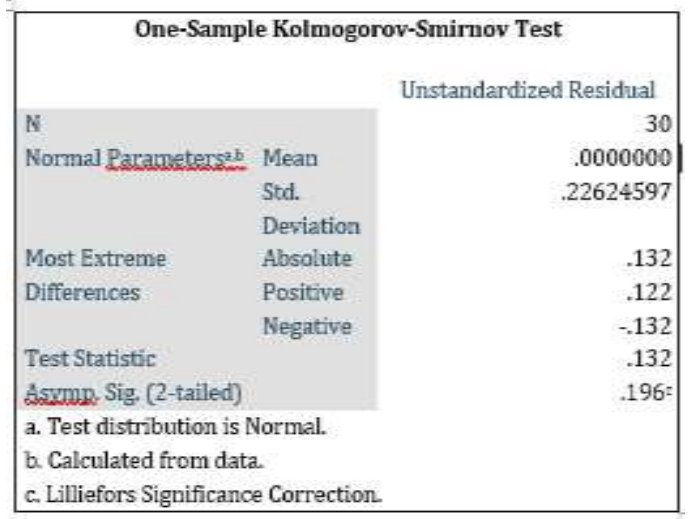

Hasil uji asumsi klasik pada table 2 menunjukkan bahwa hasil kolmogrovSmirnov dengan signifikan sebesar 0.196 dimana niali tersebut lebih dari nilai alpha yaitu 0,05 dapat dikatakan bahwa data residual terdisribusi secara normal. 
1) Uji Normalitas

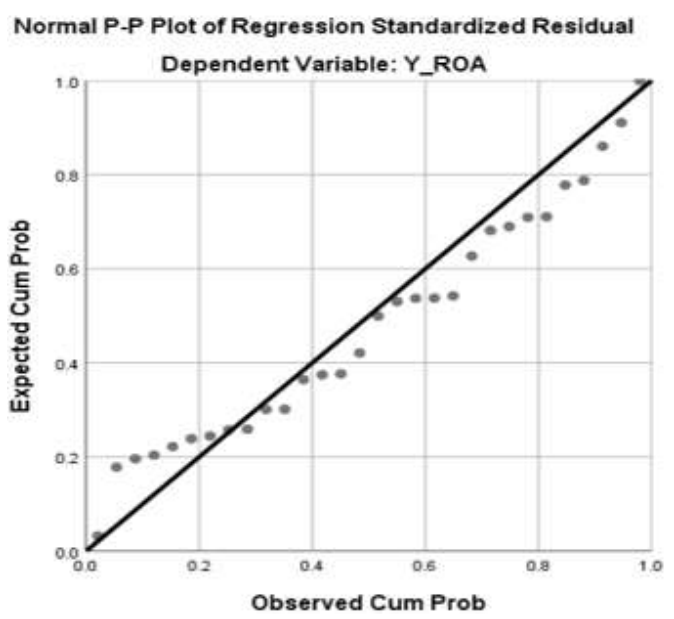

Berdasarkan diagram Normal PPlot diatas juga menunjukkan penyebaran data residual yang normal. Menurut (Ghozali,2006) uji normalitas yang dimana bertujuan untuk mengetahui antara variabel independent dan variabel dependennya terdistribusi secara normal atau mendekati normal titik titik tesebut.

2) Uji multikoliniearitas

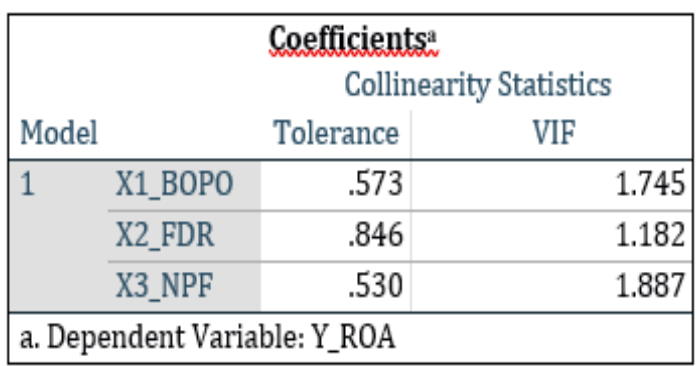

Berdasarkan pada tabel 3 diatas uji multikolinearitas melihat dengan nilai variance inflation factor (VIF) pada model regresi ini jika nilai Tolerance harus lebih besar dari 0,10 dan nilai VIF harus lebih kecil dari 10 maka dapat dikatakan bahwa data terbebas dari multikolinieritas. Hasil pengujian multikolinieritas menunjukkan semua nilai dari variable independent terbebas dari multikolinieritas dengan nilai Tolerance BOPO $(0,57)$, FDR $(0,84)$ dan NPF $(0,53)$ dan nilai VIF BOPO $(1,74)$, FDR $(1,18)$, dan NPF $(1,88)$ dibawah 10.
3) Uji heteroskedastisitas

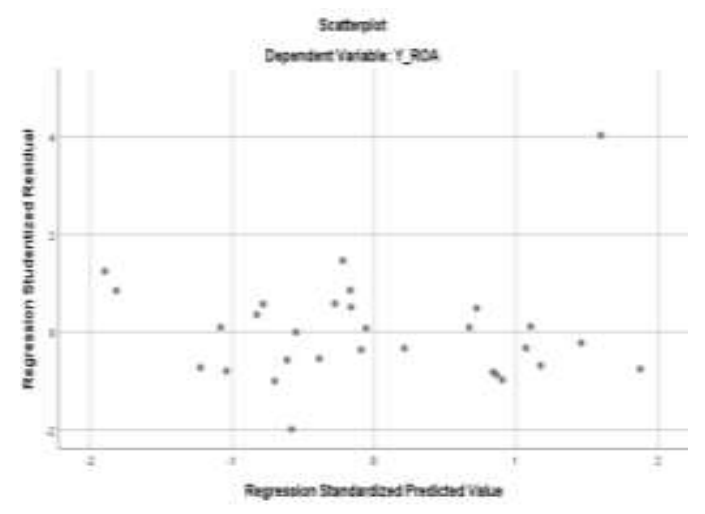

Hasil pengujian heteroskedastisitas menunjukkan titik titik penyebaran yang jauh dari sumbu $Y$ atau jauh dari titik 0 seperti pada gambar diatas dan penyebarannya tidak ada yang berdekatan itu menandakan bahwa terbebas dari heteroskedastisitas.

4) Uji Autokorelasi

\begin{tabular}{|c|c|c|c|c|c|}
\hline \multicolumn{6}{|c|}{ Model Sumarart } \\
\hline \multirow[b]{2}{*}{ Yodel } & & & Affinsted R & Sod, Entro of & Dutitin- \\
\hline & R & RSquare & Square & the Estinate & Watson \\
\hline 1 & $.930 \mathrm{z}$ & .864 & .849 & 23894 & 1850 \\
\hline a.P & Is $(\mathrm{Cons}$ & tantit), 13 _. & $212 P R, X$ & & \\
\hline b. Dep & ent thaje & ble: Y ROA & & & \\
\hline
\end{tabular}

Pada uji auto korelasi diatas menggunakan uji Durbin Watson Test (DWT Test) sebagai penguji nya dengan alpha $\propto=5 \%$. berikut pengujiannya: Hasil dari uji DW sebesar 1,850 dan Hasil Uji dl : 1.2138 dan du : 1.6498. syarat tidak terjadi autokorelasi NILAI DW $>$ DU dan DW <4-DU. Maka : 1,850>1,64981,850<4-1,6498. Yang menghasilkan tidak adanya autokorelasi dan asumsi diterima. 


\subsection{Uji Regresi Linier Berganda}

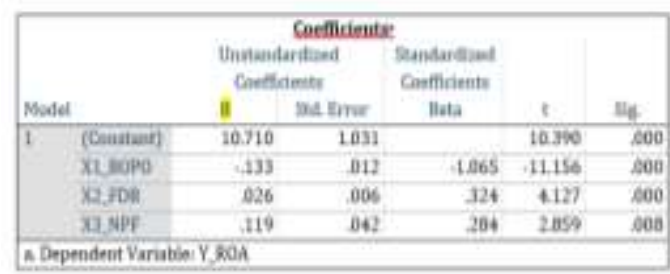

Berdasarkan hasil pada tabel 5 diatas uji regresi linier berganda menunjukkan persamaan sebagai berikut:

$\mathrm{ROA}=10.710-0,133 \mathrm{BOPO}+0,26 \mathrm{FDR}+$ 0,119 NPF e

Dari persamaan regresi linier diatas maka dapat di interpretasikan kedalam beberapa hal anatara lain seperti berikut:

a. Nilai konstanta pada persamaan diatas adalah sebesar 10.710 yang dimana dapat diartikan bahwa angka tersebut sudah lebih besar dari alpha yaitu 0,05

b. Pada pengujian ini menyatakan bahwa BOPO memiliki pengaruh negatif terhadap ROA, hasil penelitian yang diperoleh dari koefisien regresi di variabel BOPO dengan nilai yang signifikan sebesar $-0,133$.

c. Koefisien regresi FDR sebesar 0,26 dimana FDR memiliki pengaruh terhapap ROA

d. Koefisien regresi NPF memiliki nilai sebesar 0,119 maka dapat diartikan jika semakin besar nilai NPF pada perbankan Syariah maka akan berdampak pada penurunan nilai ROA nya.

\subsection{Uji Hipotesis}

a. Uji T (Parsial)

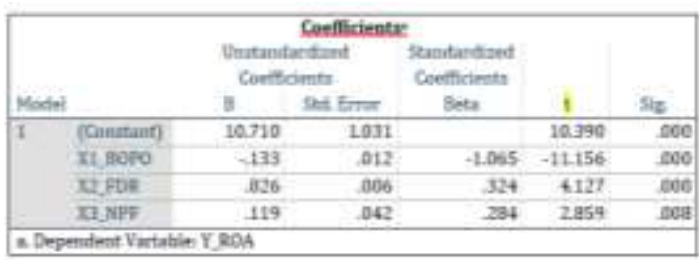

Berdasarkan tabel diatas hasil penelitian menunjukkan bahwa variabel BOPO memiliki nilai angka signifikansinya sebesar 0,00 atau $<0,05$ maka H1 diterima hal ini juga menunjukkan BOPO berpengaruh negatif signifikan terhadap ROA ini menunjukkan penelitian yang sama dengna penelitian sebelumnya yaitu oleh (Syah, 2018).

Hasil penelitian pada variabel FDR memiliki nilai angka signifikansinya sebesar 0,00 atau $<0.05$ ini menunjukkan bahwa $\mathrm{H} 2$ diterima dan berpengaruh positif ini menunjukkan penelitian yang sama dengan penelitian sebelumnya yaitu oleh (Hermina \& Suprianto, 2016).

Hasil penelitian pada variabel selanjutnya yaitu NPF memiliki nilai angka signifikansinya sebesar 0,08 atau > 0.05 ini menunjukkan bahwa $\mathrm{H} 3$ ditolak dan tidak berpengaruh terhadap ROA ini menunjukkan penelitian yang sama dengan penelitian sebelumnya yaitu oleh (Riyadi \& Yulianto, 2014)

\section{b. Uji F (Simultan)}

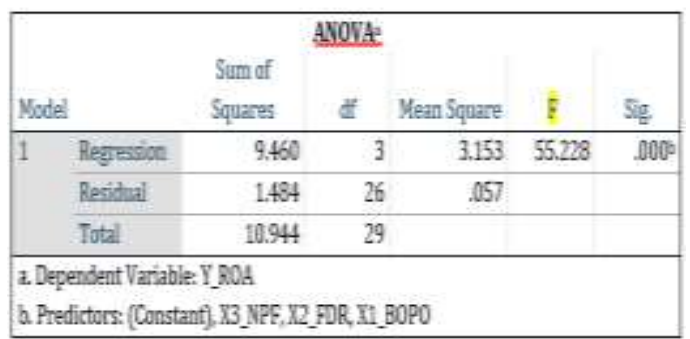

Pada pengujian uji $F$ secara simultan menghasilkan regresi nilai $\mathrm{F}$ statistic sebesar 55,228 yang dimana nilai $\mathrm{F}$ hitung ini lebih besar daripada $\mathrm{F}$ tabel yaitu 19,16 dengan probabilitasnya $0,00<0,05$ (nilai alpha=signifikan) artinya BOPO, FDR dan NPF secara Bersama sama berpengaruh secara signifikan terhadap ROA ini menunjukkan bahwa $\mathrm{H} 4$ diterima.

\section{PENUTUP}

Berdasarkan hasil penelitian dan pembahasan diatas maka dapat ditarik kesimpulan dalam penelitian ini ialah BOPO, FDR, NPF berpengaruh terhadap profitabilitas (ROA), apabila variabel independent tersebut mengalami 
kenaikan angka yang signifikan maka akan berpengaruh terhadap nilai ROA yang ada di bank umum Syariah begitu pula sebaliknya, maka dengan ini penulis mengambil beberapa kesimpulan sebagai berikut :

1. Dengan pengujian simultan (uji F) ROA yang dimana sebagai variabel dependen memperoleh nilai signifikansinya adalah sebesar 0,00 atau $<0,05$ ini membuktikan bahwa BOPO, FDR, dan NPF secara simlutan berpengaruh signifikan terhadap profitabilitas (ROA) pada perbankan Syariah di Indonesia.

2. Dengan hasil pengujian secara parsial (uji t) variabel BOPO memiliki nilai signifikansinya sebesar 0,00 atau < 0,05 ini artinya H1 diterima dan berpengaruh negatif signifikan

3. Dengan hasil pengujian secara parsial (uji t) variabel FDR memiliki nilai signifikansinya sebesar 0,00 atau < 0,05 ini artinya H2 diterima dan berpengaruh positif.

4. Dengan hasil pengujian secara parsial (uji t) variabel NPF memiliki nilai signifikansinya sebesar 0,08 atau > 0,05 tidak berpengaruh terhadap ROA ini artinya $\mathrm{H} 3$ ditolak dan tidak berpengaruh terhadap ROA, ini menandakan berapapun kenaikan angka pada nilai NPF tidak akan berpengaruh pada kenaikan atau penurunan nilai ROA.

\section{DAFTAR PUSTAKA}

Dewi, L. E., Herawati, N. T., AK, S. E., \& Sulindawati, N. L. G. E. (2015). Analisis Pengaruh NIM, BOPO, LDR, DAN NPL Terhadap Profitabilitas (Studi Kasus Pada Bank Umum Swasta Nasional Yang Terdaftar Pada Bursa Efek Indonesia Periode 2009-2013). JIMAT (Jurnal Ilmiah Mahasiswa Akuntansi) Undiksha, 3(1).
Djuwita, D., \& Muhammad, A. F. (2016). Pengaruh Total DPK, FDR, NPF dan ROA terhadap Total Asset Bank Syariah di Indonesia. Jurnal Kajian Ekonomi Dan Perbankan Syari'ah, 8(1), 281-297.

Hermina, R., \& Suprianto, E. (2016). Analisis Pengaruh Car, Npl, Ldr, Dan Bopo Terhadap Profitabilitas (Roe) Pada Bank Umum Syariah (Studi Kasus Pada Bank Umum Syariah di BEI 2008-2012). Jurnal Akuntansi Indonesia, 3(2), 129-142.

Npf, F., Profitabilitas, T., Umum, B., \& Indonesia, S. D. I. (2014). Pengaruh Pembiayaan Bagi Hasil, Pembiayaan Jual Beli, Financing To Deposit Ratio (Fdr) Dan Non Performing Financing (Npf) Terhadap Profitabilitas Bank Umum Syariah Di Indonesia. Accounting Analysis Journal, 3(4), 466-474.

https://doi.org/10.15294/aaj.v3i4. 4208

Pratiwi, D. D. (2012). Pengaruh CAR, BOPO, NPF dan FDR terhadap Return on Asset (ROA) Bank Umum Syariah di Indonesia. Fakultas Ekonomika Dan Bisnis, 85.

Riyadi, S., \& Yulianto, A. (2014). Pengaruh Pembiayaan bagi Hasil, Pembiayaan Jual Beli, Financing to Deposit Ratio (FDR) dan Non Performing Financing (NPF) terhadap Profitabilitas Bank Umum Syariah di Indonesia. Accounting Analysis Journal, 3(4).

Sari, D. W., \& MAHFUD, M. K. (2013). Pengaruh Pembiayaan Jual Beli, Pembiayaan Bagi Hasil, Financing To Deposit Ratio, dan Non Performing Financing terhadap Profitabilitas Bank Umum Syariah di Indonesia Periode 2009-2012. Fakultas Ekonomika dan Bisnis.

Sudarsono, H. (2008). Bank dan Lembaga Keuangan Syariah Edisi Ketiga. Cetakan Pertama. Yogyakarta: Ekonisia. 
Syah, T. A. (2018). Pengaruh Inflasi, BI Rate, NPF, dan BOPO terhadap Profitabilitas Bank Umum Syariah di Indonesia. El-jizya: Jurnal Ekonomi Islam, 6(1), 133-153. https://doi.org/10.24090/ej.v6i1. 2051

Surat Edaran Bank Indonesia No.06 $/ 23 / D P N P$

https://www.bi.go.id/id/archive/arsipp eraturan/Pages/ketentuan\%20per bankan.aspx.

Undang-Undang No. 10 tahun 1998 Tentang Perbankan

https://id.wikisource.org/wiki/UndangU ndang Republik Indonesia Nomor 10 Tahun 1998 